\title{
Leadership Style, Ethics, and Strategy in Indonesian Navy - Case Study: Leadership of Rear Admiral Agung Prasetiawan, M.AP, (2017-Present) Commander of Kolinlamil
}

\author{
Faurna Lusiani Pakpahan \\ Doctoral Program, Human Resource Management, State University of Jakarta \\ J1. Rawamangun Muka, RT.11/RW.14, Rawamangun, Jakarta Timur, 13220 \\ Kasubdis Garbia Disku Kolinlamil Jl. Raya Pelabuhan Pos IX Tanjung Priok \\ E-mail: lucianipapahan@gmail.com
}

Hady Efendy (Corresponding Author)

Education Practice and Academic Consultant

E-mail: efendy_hady@yahoo.co.id

Received: Sep. 13, 2017 Accepted: Oct. 3, 2017 Online published: Oct. 16, 2017

doi:10.5296/ijhrs.v7i4.11775

URL: https://doi.org/10.5296/ ijhrs.v7i4.11775

\begin{abstract}
In an organization, leadership in an organization exists from a long time ago to the present, and leadership is a very important thing. A leader must use the right style to lead the organization he leads. The leader must also have good ethics in leading the organization and use appropriate strategies, so that organizational goals can be achieved. The purpose of this paper is to find out how much influence of leadership style, ethics and strategy what is used by an organization leader in a military institution that is Navy at Tanjung Priok Command Military Traffic (Kolinlamil) Jakarta, to be able to achieve organizational goals under leadership of Rear Admiral Agung Prasetiawan, M.AP. Kolinlamil is the main command in coaching and operations, which in the field of guidance of Kolinlamil is directly under the head a navy staff (Kasal), while the field of operations is directly under the Commander of the Indonesian Military (TNI). Kolinlamil is a military institution whose main task is to shift military or civilian forces from one area to another based on existing rules and orders.
\end{abstract}


Keywords: kolinlamil, leadership style, ethics and strategy, navy

\section{Introduction}

In organizational life, leadership style of a leader is important to note. Leadership in an organization, required to be able to find the right leadership style for the organization. Therefore a leader must be able to understand and understand the behavior of individuals within the organization led, and find the right leadership style for the organization. To obtain an organization that is conducive and ideal, it is necessary, the application of ethics in the organization, and to achieve organizational goals then a leader must use appropriate strategies and support the leadership style applied to the led organization.

Efforts to build the effectiveness of leaders lie, solely on the debriefing dimensions of technical skills and conceptual skills. The effectiveness of managerial activities and their impact on organizational performance depends heavily on the leader's sensitivity to use his personal skills. Such personal skills include the ability to understand individual behavior and group behavior in its contribution to organizational dynamics, the ability to modify behavior, the ability to understand and provide motivation, the ability to understand the process of perception and the existence of effective communication, the ability to understand the relationship between the concept of leadership of political power in the organization, The ability to understand conflict and negotiate its completion, as well as the ability to construct an ideal organizational culture. Creativity is important for decision making, it allows decision-making to better understand the problem, including issues that cannot be seen and understood by others, but in fact many leaders in decision-making do not pay attention to good leader behavior.

Currently the organization in which we serve is the Military Traffic Command, which is a military agency engaged in military transport by using military transportation namely the Indonesian War Ship (KRI). The Kolinlamil address in Highway Pos IX port of Tanjung Priuk Street, north Jakarta. Where the leader, is under the leadership of Commander-in-Chief of Kolinlamil by an active TNI rank of Rear Admiral (Laksda), a navy with a two star rank. Of course, each leader has their own leadership style (in contrast to previous leadership styles), although leadership in the military is clearly based on the leader's orders. The result is that there are some problems, resulting from the transformation of style, ethics, leadership strategy, the many rules, the standard operating procedure (SOP), and the regulation and organizational culture, and the organizational structure that is the placement of new people in office, all of which are changed and done In the era of the leadership of Rear Admiral of TNI Agung Prasetiawan, M.AP so that during this leadership transformation, there were several obstacles by some of the members of Kolinlamil.

\subsection{Formulation of Problem}

Based on the background that the author has conveyed, the authors can convey the formulation of the problem includes:

1. What is the leadership style applied by Rear Admiral Prasetiawan, M.AP at this time? 
2. What is the leadership ethic applied by the Rear Admiral of TNI Agung Prasetiawan, M.AP at this time?

3. How is the strategy implemented by Rear Admiral Prasetiawan, M.AP in leading Kolinlamil today?

\subsection{Purpose of Writing}

Based on the background and problem formulation in this research, the purpose of this research are:

1. Analyze the leadership style applied by Rear Admiral TNI Agung Prasetiawan, M.AP in leading the current Kolinlamil.

2. Analyze leadership ethics applied by Rear Admiral TNI Agung, M.AP in leading the current Kolinlamil.

3. Analyze the strategies adopted by Rear Admiral TNI Agung Prasetiawan, M.AP in leading the current Kolinlamil.

\subsection{Research Methodology}

The author uses study literature including website browsing analysis without the use of in-depth research or direct interviews to the character who became the case study here, to complete this research.

\section{Literature Review}

\subsection{Definition of Leadership and Leadership Style}

Leadership is the activity or art of influencing others to want to cooperate based on the person's ability to guide others in achieving the goals desired by the group. According to Tead: Terry; Hoyt (in Kartono 2003). Leadership styles are behaviors and strategies as a result of a combination of the philosophies, skills, traits and ethics that leaders often show when conducting leadership activities in a group or organization.

The success of a leader is determined by its properties, from the results of Charles and David's research these traits are:

1. Intelligence: Leaders must be smart.

2. Visionary: Leaders must have maturity and social discretion.

3. Confidence: the leader must have a steady confidence, supported by the ability he has.

4. Communicative: Leaders must have the ability to communicate with each person in any type. Leaders must have the ability to understand the individual.

5. Motivation: Leaders have the urge to always appear as a solution.

There are six leadership styles, quoted from leadership books (Wibowo, 2016):

1. Autocratic leadership style. This style is said to be that leadership is centered on a leader or a directive style. It is characterized by an enormous number of leads and very limited participation of subordinates in planning and decision-making. What stands out is the giving of orders. An autocratic leader is someone who rules and wants decisions. 


\section{Macrothink}

International Journal of Human Resource Studies

ISSN 2162-3058

2017, Vol. 7, No. 4

2. Democratic leadership style. This leadership style is the ability to influence others to be willing to work together to achieve the objectives that have been established with various activities to be undertaken determined jointly between the leadership and subordinates. Leadership is done with equality, consultative or participative leadership. Leaders with the men formulate action Decision together.

3. Delegative leadership style. Leaders rarely provide direction, decisions have the character of: all humans are immature, overprotective, seldom giving their subordinates the opportunity to make decisions, rarely giving subordinates to initiative, and rarely allowing their subordinates to develop creative and fantasy.

4. Bureaucratic leadership style. This style is described as "rule-based lead". Leaders lead their adherents based on strict rules, rigid, decisions taken strongly influenced by his personal character.

5. Laissez Faire leadership style. This style is a member to take the initiative. Leaders use less power.

6. Charismatic leadership style. The advantage of this style is being able to attract people, his personality style is visionary (usually). Charismatic style leaders, usually very fond of change and challenge.

\subsection{Leadership Ethics}

Leadership ethics are ways that are generally considered true by a group or a community in an attempt to influence others to achieve a common goal that an organization possesses.

In a major Indonesian dictionary published by the Indonesian Ministry of Education and Culture, ethics is formulated in three meanings:

1. The science of what is good pa fund is bad and about moral rights and obligations (morals).

2. A collection of principles or values pertaining to morals.

3. The value of right and wrong that a group or society holds.

According to Burhanudin Salam (1997), ethics is a branch of philosophy that speaks of the value of norms and morals that determine human behavior in life. According to Simorangkir (2001), ethics is a human view in behaving according to size and good value.

The opinion of experts according to Bertens (1993: 4), the term ethics comes from the ancient Greek. The Greek word ethos in singular form has many meanings, but in the plural (attitude) it means custom. This ethical word has been used by the great Greek philosopher Aristoteles (384-322 BC) already used to denote the moral character. The science of what is commonly done by the science of customs.

So the leadership ethics are:

1. Ethics is the intention, whether the act is allowed or not according to the good or bad intentions as a result. Ethics is a set of ways, to do the right deeds as expected. 
2. Ethics is the conscience, that is how to be ethical and good that actually arise from his self-consciousness, ethics is the visible normality of his outward attitude filled with courtesy and kindness.

3. Ethics are absolute is absolute, non-negotiable.

4. The ethics of entry into force does not depend on the presence or absence of others present.

Each organization must have a vision and mission, and each organization would want to achieve organizational goals. For that every leader must have a strategy or a way to achieve organizational goals. Leadership strategy is the way or taken by the leader so that the goal can be achieved. Leadership strategies can be achieved, by: the leader must have a clear vision, and be able to assess everything, the goal is that leaders can make decisions, and leaders can create future leaders, can communicate effectively, and be able to take risks (have a backup plan ). Leadership is a complex phenomenon involving leaders, followers and situations where leadership is the process of influencing organized groups toward the completion of the goals of an organization both formal and informal (Hugest, Ginnett \& Curphy, 2009).

Leadership strategy is integrated and integrated planning. It is carried out with the execution of activities commanded by a group leader both official and unofficial.

Leading a group both formal and informal is a job with a very heavy responsibility both in small and large groups. Wolf (2015: 14) argues that the strategies that effective leaders must have are:

1. Bring people together to work as a team. Bringing people to work together as a team. Leaders guide teams, departments or groups and it is not easy to lead a team of diverse groups of people.

2. Motivate people to perform. That can motivate people to perform, leads must be able to resuscitate the lead that they do have awareness to work, and leaders must be motivated by being a media example for the group.

3. Take responsibility for bottom-line result. That is a leader is required to always pay attention to his subordinates like working together with each team, department or group that exist in an organization, always ask for advice, opinion from which he leads.

4. Make difficult decision. It is the duty of the leader to hire the right person, remove the wrongdoer, and ask for advice on his or her performance, so that the employees he leads can be even better.

5. Create positive energy. Create positive energy, so be a role model for who led to the organization.

\section{Discussion}

Kolinlamil is the main command of navy operations addressed at Tanjung Priok postal port of IX. Formed since July 1, 1961 under the name Military Sea Transportation Unit (Dalmil). Kolinlamil field direct coaching under the Head of Naval Staff (Kasal), while the field of operation is directly under the Commander of the Indonesian National Army (TNI). Kolinlamil currently is headed by a Rear Admiral Agung Prasetiawan, M.AP. In the command 
system of the existence of Kolinlamil oversees Satellite Military Unit (Satlinlamil) Surabaya and Jakarta. The establishment of Dallamil was formed to support the logistical interests of the Navy and the TNI including the interests of the government in the field of sea transport, so identical to the military sea transport and which used is the Indonesian republic war ship (KRI) and currently Dallamil title to be Kolinlamil.

\subsection{Leadership Style Implemented by Rear Admiral Agung Prasetiawan, M.AP}

The leadership of Rear Admiral TNI Agung Prasetiawan, M.AP. is a real and clear military leadership, but he is a good leader and desirable by all members of Kolinlamil. In the structure of the Indonesian army (TNI), the navy is known as a hierarchical system, where there is a differentiation of strata/level in membership, but other evidence shows that Agung Prasetiawan is a leader who is familiar with his members when he is newly appointed as a leader in Kolinlamil, he held a ship's commander's hour on all his members including chief of staff, assistants and heads of department, civil and military service, all collected on the deck of the Indonesian Republic Warship (KRI) Banda Aceh. All participants sit and eat together with the same food menu. This indicates the presence of togetherness among all participants. Likewise, when he got the rank to become Rear Admiral, he gathered all his members without exception on the KRI Banda Aceh deck, and teleconference with a Cross-Unit Commander (Dan satlin) residing in Surabaya and a member of Satlinlamil Surabaya, as an expression of his gratitude. In addition it also held "the commander's hour", and ate together with all members. All the members were delighted to be grateful for the promotion he became the Rear Admiral of the Navy.

In the navy there is a clear hierarchy, such as the enlisted strata, non-commissioned officers are prohibited from entering the "long room" area of officers without any clear need as the official duty. They are also forbidden to eat in the same table with the officers. Limitations and restrictions for a person who has a lace strata to call a higher strata with a father, mother or real name. They should mention the rank or strata of the person being called. The clear statement inherent in the soul of the soldier is the word "permission" which is always pronounced by a junior to a senior, or from a subordinate to the boss. In the era of leadership of this Kolinlamil commander, who has not been long in office, many things have happened and are more dominantly positive for the organization and for its members.

In the era of the leadership of Commander-in-Chief of Kolinlamil Rear Admiral Agung Prasetiawan, M.APP, who has not been long in office, much has happened and is more dominantly positive for organizations and members. Rear Admiral Agus Prasetiawan, M.AP. is a military leader of the navy, who heads the main command of operations (Kolinlamil) to support the movement of military transport by sea by warship of the Indonesian republic (KRI), and has members at the center of Jakarta's Kolinlamil and satlinlamil Surabaya. Agung Prasetiawan is a firm leader, commitment and discipline. For him the military is synonymous with violence but does not have to be tough and anarchic. He is a leader who can interact upward, sideways can also embrace down. He is able to convey to all members through assistants and heads of departments on the vision and mission of Kolinlamil to all members, so that all members know and understand what he means. He encourages the vision and 
mission to be transformed into action that can be demonstrated in action or reality. Commander-in-Chief of Kolinlamil is the chief commander of good command, authoritative, visionary, fatherly, but firmly in accordance with the rules. He is respected, but not feared and willing to receive input from members, of course according to existing rules, and there is awareness of the condition of its members, as well as the surrounding environment.

He emphasized that the task must be carried out, and each assigned task must have a report from the actor to the assignor. Each leader has a personality, character, nature and style in leading the organization he leads. He is a leader of a military leadership style (dominant), he does not dispel the image that he is a military, a true soldier who holds the oath of soldiers, the eight are mandatory ABRI and "Tri Sila" of TNI AL.

On the one hand, he acts as a superior, but one side acts as a father who will listen to complaints, suggestions, input from his members. He wants to give advice if necessary, provides solutions if there is a problem and for the leaders below him is overwhelmed to finish it. He has a vision, in which the vision is transformed into action, he gives understanding, directions for his people to work as well as possible so that Kolinlamil can be more advanced and his mission vision can be achieved. He acts as a true military, firm and authoritative, giving command to his members, done and had to report back to what he had done. Firmly, he led the Kolinlamil which was the main command (Kotama) of operations that supported his military sea transport activities. The force undertaken by the Commander was to lead his soldiers and his men, so that organizational goals can be achieved.

\subsection{Implemented Leadership Ethics Rear Admiral TNI Agung Prasetiawan, M.AP}

Ethical leadership is a leadership that demonstrates behavior that is normatively appropriate through personal actions and interpersonal relationships (inter-personal with others both within the organization and those in the external environment of the organization). Ethics does not address human conditions or circumstances but about how humans should behave. The leadership ethics that can be seen from the period of leadership of Rear Admiral TNI Agung Prasetiawan, M.AP, are: having a high morality in the lead, the commander has a good moral in the execution of duties, able to be responsible for the mandate and position given to him. With high morality is expected to be an example for his subordinates. Having good ethics is a leader who can place himself / herself according to the standards of behavior deemed correct by the local community in particular. Leaders who have a strong personality is a leader who can control the emotional level, feelings, traits, temperament, character and personality are stable in carrying out the assignment.

As Commander of the Military Command is a firm and wise leader, he maintains closeness with his assistants, heads of departments (Kadis) and his elders. The Commander of Kolinlamil is very concerned about the conditions of the members he leads, from the very bottom to the middle officers. What if anyone died, sick and stricken disaster, he always took the time to attend to see the family members, especially in the situation of grief. He also enjoys joint sporting events, socialization, religious festivals, and other cooperative activities, although we know that in the military having a clear command line of command in leadership and military is synonymous with violence, the commander is concerned with his members, 
opening opportunities for members to convey creative ideas in activities in Kotama. He values and cares for everyone. Another part of his concern is the importance of religious life, the sense of mutual respect, even as a military but the other side of human life must remain and be preserved.

The existence of honesty and openness, as Commander of Kolinlamil, he has a very good ethics. Always invite assistants and heads of departments (senior Colonel) to hold meetings and discussions, related to activities to be performed and he has an open nature. Assistants and heads of departments under the leadership of Kolinlamil Chief of Staff are, in this case headed by a one-star High Officer or First Admiral, and currently headed by Admiral Sugeng Ing Kaweruh.

Socialization, the commander of Kolinlamil has an ethics or attitude of care to the environment around the organization by establishing good relations with the parties around the Kolinlamil region, that is with the Police Resort (Polres) of north Jakarta, Jakarta conventional Jakarta, Police Water and Air (Polairud), the banking which are located in the territory of Tanjung Priuk, and the local people. Every activity related to Kolinlamil, religious activities, etc. always try to invite and involve the surrounding community and the surrounding institution in the area of Kolinlamil. The feeling of togetherness and outsiders is involved in certain activities undertaken by Kolinlamil, so they know and understand about Kolinlamil.

\subsection{Implemented Leadership Strategy Rear Admiral TNI Agung Prasetiawan, M.AP}

Rear Admiral of TNI Agung Prasetiawan, M.AP has the hope that all of its soldiers and civil servant staff can keep up with the times, science, so that soldiers are able to use technology to support the interests of the Kolinlamil organization, where Kolinlamil mission and vision can be achieved. To achieve this, the Commander of Kolinlamil held policies such as:

\subsubsection{Significant and Enhanced Empowerment of Kolinlamil Members}

It's done by improving the ability of its members that is by:

1. Motivate its members to be willing to follow courses and schools to a higher level, to be more qualified in their field. For a bachelor (S1), it is advisable to want to follow the master's program (S2), as well as for the members, Especially middle officer of navy in kolinlamil encouraged to go to doctoral program (S3), suggested linear with previous program, and strived which is related to field assignment, so able to support in its daily service. Commander, stimulates middle officers to think, more advanced and can become a person who can adapt with the environment and can keep up with the times, also operate the existing technology. Can be a tough soldier with broad insight, support the organization's programs well, so that the vision and mission can be achieved. He wanted the soldiers of Kolinlamil to become navy soldiers who can follow the times, and become professional soldiers in their field and world-class.

2. Building supporting facilities in kolinlamil, such as sports facilities, building futsal field, repairing badminton, tennis courts, adding fitness equipment in fitness room for officers and members and health and worship facilities. 
3. Conducting courses to upgrade the skills of all members, for example, the KRI Commander's Skill Course and the KRI head of logistics department (Kadeplog) KRI course. All done to make the ship's crew more professional in their field. Provides courses on how to become a ship commander qualifed and capable of leading the organization he carries and of course this is aimed at the seafarers' corps, who will and have become commander of KRI. Kadeplog course, carried out for suply officers who mainly become KRI Kadeplog. It is expected that the officers of the corps supply ship can perform the task according to the rules. 4. External organization of the leadership era Rear Admiral TNI Agung Prasetiawan, M.AP, cooperates with the State University of Jakarta to make its officers become officers who want to study, higher level than what the officers have got, there is cooperation for the program masters and doctoral. During the process of teaching and learning the officers united with the general students. He also established good relations with various parties and agencies in the neighborhood around kolinlamil. Conducting joint events between agencies, so as to create good relationships and communication.

\subsubsection{Technology Strategy and Empowerment of KRI (Existing Military Means of Transportation)}

The presence of KRI and military transport facilities of the majority-aged military is a constraint faced by the Navy. In the era of the leadership of Rear Admiral TNI Agung Prasetiawan, M.AP, empowered maximally the use of existing military means (KRI), to support all military transport activities between regions carefully and calculated. In addition it also carries out regular maintenance to the ships under Kolinlamil to continue to support military operations or humanitarian activities that have been set by the leadership. He also strives to convey to the leaders above him if possible that old KRIs can be replaced with new KRIs with younger age, so the task of the organization can be more quickly implemented, safe and comfortable. The Commander of Kolinlamil also proposed that the new KRI be established, thus increasing the power of military sea transport in the navy.

At the leadership of Rear Admiral TNI Agung Prasetiawan, M.AP, more empowered to use the Kolinlamil website, to provide information about what all the activities have been done and planned. Websites serve to provide all activities and information carried out in Kolinlamil along with the navy and outside parties. Teleconference techniques are also used for activities between leaders and regions.

\subsubsection{Working Culture Strategy Effective}

As an institution then Kolinlamil use guidance base to perform action based on Trisila TNI AL and Sumpah Prajurit. Every member of the navy who is serving in Kolinlamil and civil servants must obey the rules to serve from Monday to Friday with the typical rules or standards in the navy. The working culture that is carried out is a military work culture with a clear and decisive command line system. All executed by order and finished work should be reported to the giver of the order. The morning ceremony at the ceremonial court starts at 07.00 and the afternoon ceremony at 15.30 for Monday to Thursday and on Friday evening the afternoon ceremony starts at 16.00 . 
Every Tuesday and Friday, the morning ceremony is held regularly until 10:00 am. Friday prayers are held for those who are Muslims. On Wednesday morning, the morning ceremony was done by religious counseling according to the religion, followed by the practice of marching line in the field until 08.00. Every month on the 17th held regular flag ceremony. On special occasions special ceremonies and commander's hours are held by the chief commander of Kolinlamil.

All existing activities have underlying rules and every civil servant and serviceman should be obliged to follow. Leaders think the best thing for the members of Kolinlamil, where there is time for the morning ceremony, socialization, sports, worship, entertainment, and for the sick provided the hospital or clinic to treat the illness, of course for the Hospital is the existence of the navy hospital that from day to day more advanced condition.

\subsubsection{Empowerment of Labor Strategy}

During the leadership of Rear Admiral Agung Prasetiawan TNI, every soldier and staff of civil authorities must follow the rules, to serve on a given day and time. They must fill out the attendance list. They are obliged to carry out the tasks assigned by the leadership and must report on the tasks that have been given by the leadership and submit reports that have been done (report). If they are sick, the permit request must be clear, there should be a report and supporting evidence. All regularly and must be obeyed by the members without exception if in violation will be subject to sanction.

For the rights of servicemen and civil servant staff earned each month in the form of salary and performance allowances. The time of receipt of salary and allowances is at the beginning of the month for salary and in week 2 for allowances, depending on the readiness of the paymaster.

Preparation and implementation of the strategy undertaken during the leadership of Rear Admiral Agung Prasetiawan, M.AP, there are several problems such as the presence of several Navy Middle Officers performing doctoral education (S3) have ineffective working time. This is due to the importance of education that must be done outside working hours as well as the time needed to meet with lecturers as well as looking for reference books in the library. This condition interferes with the effective time to work while the costs for job titles and performance allowances must continue to be provided.

\section{Conclusion}

Based on the above explanation about the leadership of Rear Admiral Agung Prasetiawan, M.AP, above, it can be said that leadership has different leadership styles, ethics and leadership strategies. The leadership style implemented by Rear Admiral TNI Agung Prasetiawan, M.AP, is the leadership of a genuine military, giving command-line commands, each commanding member, is obligated to carry it out, then reporting on the orders that have been carried out. He is indeed the leader desired by every soldier and staff of civil servants in Kolinlamil, he is able to influence members of Kolinlamil to follow what he planned. He has the ability to transform his vision and mission into real action to support the activities of the Kolinlamil organization. He is a leader who has a high moral in the lead, has a sense of 
responsibility and able to provide good examples for all soldiers. This is evident in everyday activities through good speech and real action in everyday life. He has good ethics, is able to position himself according to his function and capacity, can control his words and deeds, stable emotional level, good character and character, firm but wise. He also fostered good relations as a commander of assistants, heads of service and all his members by holding commemorative hours, special ceremonies, and sports together. He maintains good relations with other agencies close to the Kolinlamil, and also maintains good relationships in accordance with procedures with central agencies and officials at the center as well as local communities.

As Commander-in-Chief Kolinlamil also applies honesty and openness, inviting assistants and heads of departments to discuss ongoing activities as well as financing budgets. He also opens opportunities for members through leaders who participate in meetings and discussions, so that suggestions or suggestions to be submitted for the good of the organization can be given directly with reference to prevailing military rules.

With his military leadership style is firm and authoritative able to provide an example for his men to become a good soldier. He also has a good strategy with the condition of the vessel Kolinlamil the problematic majority of the age factor, he still ordered the crew of ship to perform maintenance on a regular basis so that the ship can be used with limited conditions. To support the existing operational activities, Kolinlamil ships are prepared to be able to perform the tasks to the fullest. This is done by considering the safety factor and prepared of course with reliable ship commander, full of calculations and supported by the crew of the ship skilled and loyal.

\section{References}

Abah, R. (2014). Menjadikan Sapta Marga, Sumpah Prajurit Dan 8 Wajib Tni Sebagai Nafas Disiplin Prajurit. https://abahrumadi.blogspot.co.id/2014/09/blog-post.html (Sept. 15, 2014). Aynul, L. (2009). Definisi Kepemimpinan. https://kepemimpinan-fisifuh.blogspot.co.id/. (March, 11, 2009)

Bertens, K. (1993). Etika, Jakarta: PT Gramedia Pustaka Utama.

Bob, S. (2015). 15 Pengertian Etika Menurut Para Ahli. https://www.pengetahuan.com/2015/10/15-pengertian-etika-menurut-para-ahli-terlengkap.ht ml. (October, 5, 2015).

Burhanuddin, S. (1997). Etika Sosial: Asas Moral dalam Kehidupan Sosial. PT RINEKA CIPTA. Jakarta.

Huges, Ginnet, \& Curphy. (2012). Leadership diterjemahkan oleh Putri Izzati, Jakarta: Penerbit Salemba Humanika.

Kartono, K. (2003). Pemimpin Dan Kepemimpinan. Jakarta: PT. Raja Grafindo Persada. Simonangkir. (2001). Etika. Cipta Manunggal Jakarta. 


\section{Macrothink \\ International Journal of Human Resource Studies \\ ISSN 2162-3058 2017, Vol. 7, No. 4}

Sondang, P. S. (2016). 5 Gaya Kepemimpinan.

https://etalasepustaka.blogspot.co.id/2016/05/5-gaya-kepemimpinan-menurut-siagian.html. (2016)

Wibowo. (2016). Kepemimpinan Pemahaman Dasar, Pandangan Konversional, Gagasan kontemporer. Jakarta: PT.Raja Grafindo Persada.

Wolf, J., \& Ken, S. (2007). Seven Disciplines of leader. New Jersey: John Wiley \& Sons.

\section{Copyright Disclaimer}

Copyright for this article is retained by the author(s), with first publication rights granted to the journal.

This is an open-access article distributed under the terms and conditions of the Creative Commons Attribution license (http://creativecommons.org/licenses/by/4.0/). 